\title{
A representação da África na música italiana contemporânea: do após-guerra até hoje
}

\author{
Luca Bussotti \\ Doutor em Sociologia do Desenvolvimento (Universita degli Studi, Pisa) \\ Investigador Auxiliar no Instituto Universitário de Lisboa \\ Lisboa, Portugal \\ labronicus@gmail.com
}

Este artigo visa analisar como a música italiana contemporânea tem representado a África e os Africanos no período Pós-Segunda Guerra Mundial. Numa primeira fase, a música italiana negligenciou por completo a África nas suas canções, provavelmente por causa do seu passado inglório colonial e fascista. Depois de algumas canções "leves" que, ao longo dos anos Sessenta, representaram os Africanos numa maneira folclórica, alguns compositores comprometidos propuseram uma imagem diferente da África: primeiro, como um mundo longínquo, desejável e "nostálgico", e depois denunciando as condições dos imigrados na Itália, sobretudo de origem africana. Finalmente, um ponto de vista mais interno emerge graças a jovens rappers Ítalo-Africanos (assim como Ítalo-Asiáticos), capazes de "inverter" a perspetiva com que a música italiana tinha olhado até então para África. O artigo serviu-se de uma metodologia qualitativa, baseada na análise de conteúdo das canções e usando algumas entrevistas dos cantores presentes na esfera pública.

Palavras-chave: imagem, África, compositores, rappers Ítalo-Africanos, cidadania.

\section{Introdução}

A representação da África e dos Africanos por parte da música italiana tem sido historicamente relacionada com colonialismo e fascismo, expressando um poderoso aparato ideológico de natureza basicamente eurocêntrica e racista ou, na melhor das hipóteses, paternalista (Bussotti, 2016). Com a queda do fascismo, a África desapareceu do cenário musical italiano. 
Este trabalho procura analisar a evolução das formas de representação da África, migração africana e dos próprios Africanos na música italiana, a partir do fim da Segunda Guerra Mundial até hoje. A ideia que sustenta o artigo é que houve fases diferenciadas nas modalidades com que isso foi feito: na primeira, a África era pouco mais do que uma ausência, representada duma forma folclórica; na segunda, ela tem sido usada como símbolo para fugir à civilização ocidental, na esteira duma tardia reminiscência do mito do bom selvagem; na terceira a abordagem torna-se mais realista, devido, a partir dos anos Noventa, à presença de migrantes sobretudo africanos na sociedade italiana. Finalmente, na quarta fase, a "GenerationTwo" (G2), composta por artistas Italo-Africanos, rompe com todas as tradições anteriores, adotando a cultura hip-hop e o rap como sua forma privilegiada de expressão artística e propondo temas inovadores com perspetivas originais. Trata-se de uma inversão paradigmática, em que a África é tratada mediante o olhar de duas subculturas: a juvenil-urbana e a identitária de artistas de origem africana ou mestiços, criados e educados na Itália. A África torna-se sujeito ativo das suas próprias representações e reivindicações, coisificando por sua vez a Itália e os italianos: estilos musicais, ritmos e linguagem "alternativos” acompanham esta mudança radical.

\section{Quadro teórico e questões metodológicas}

A música é o produto duma certa altura histórica. E a música "serve" específicos interesses sociais, de acordo com o tipo de regime político, as margens de liberdade de expressão, o cometimento dos cantores.

Considerando o sempre problemático relacionamento entre sociedade e música na modernidade (Keller, 1996), é possível dizer que até aos anos Setenta uma boa parte da crítica musical era feita com base nos ensinamentos de Marx e dos seus epígonos. A ideia que tinha sido propalada por Marx, na Ideologia Alemã (escrita entre 1845-1846, mas publicada apenas em 1932), englobava a música nas artes burguesas, contribuindo à manutenção da ordem social vigente. Max Weber considerava a música moderna (sobretudo a romântica) como um dos meios mais eficazes para levar a cabo o processo de racionalização da modernidade; mas este tipo de análise não teve muitos seguidores, diferentemente da tendência neomarxista (Monceri, 1999). Essa última afirmou-se no século XX mediante à Escola de Frankfurt, que refletiu criticamente acerca da função social da música, introduzindo perspetivas inovadoras, tais como a análise dos públicos musicais, o significado social das artes, o papel social e político dos músicos. Walter Benjamin, em 1936, considerava o trabalho artístico como funcional para os regimes totalitários daquela altura, deixando uma pequena possibilidade de resgate apenas à música socialmente e politicamente comprometida (Benjamin, 2008). Adorno expressou ideias ainda mais radicais: a arte sempre serviu os interesses da igreja e das classes privilegiadas. A única arte autêntica, fora do processo de massificação, seria a independente dos condicionalismos do mercado (como a música de Schönberg), introduzindo a ideia da música como 
"mónada" (Adorno, 2004). Marcuse rompe com a tradição crítica, argumentando que a arte tem uma dimensão transcendental em comparação com a realidade, sendo essa sua caraterística que lhe atribui a capacidade de manifestar formas de resistência e rebelião de tipo social (Marcuse, 1972). Mas foi com Habermas que a arte e, nomeadamente a música, entram a pleno título como elemento decisivo na construção da esfera pública (Habermas, 1992). Hoje, pretende-se basicamente perceber qual a fruição da música por parte dos indivíduos, se e como a música reproduz as divisões sociais, étnicas, de género e de classe, como é que se dá a produção coletiva da música (Roy; Dowd, 2010).

Com efeito, os três principais domínios de estudo da música do ponto de vista sociológico são a produção, a análise dos conteúdos, o consumo dos produtos musicais (Dowd, 2007). Este artigo insere-se na segunda dessas linhas de pesquisa, procurando pontes com a análise do relacionamento entre movimentos sociais e música (Eyerman; Jamison, 1998; Hargreaves, 2015) e entre contextos históricos e culturais e modalidades de representação dum certo sujeito (África) na música popular italiana.

A música desempenha funções diferentes consoante os específicos contextos históricos, sociais e políticos em que ela está mergulhada, podendo ela ter a capacidade de denunciar temáticas ou situações sensíveis. Por exemplo, em casos de regimes autoritários, uma grande contribuição em termos de resistência foi dada pelos músicos na antiga União Soviética, principalmente nos últimos anos do comunismo (Street; Hague; Savigny, 2007); assim como na Primavera árabe a música, graffiti, social network tiveram uma função relevante em “acordar” a sociedade (Le Vine, 2015). Na África Subsaariana, um importante movimento social e cultural emergiu, sob a bandeira do hip-hop, no contexto urbano de vários países, permitindo à "Juventude Africana participar do discurso social, político e econômico a nível nacional e mundial" (Clark, 2012, p. 23, tradução nossa). Nos países maduros do ponto de vista do desenvolvimento democrático, a cultura Hip-hop e o rap foram expressões de minorias culturais e étnicas, ou de verdadeiras subculturas, principalmente as juvenis ou as "étnicas", como os Afro-Americanos e as comunidades de migrantes africanos na Europa (Kitwana, 2002; Osgerby, 2014).

A imagem da África na música ligeira italiana ${ }^{2}$ representa um ótimo exemplo das diferentes funções que a arte pode exercer em específicos contextos históricos e sociais; de fato, a África tem sido o símbolo da evasão e dos estereótipos mais banais, a alavanca duma comprometida crítica política e social, o meio de lutas identitárias, redesenhando diferentes relacionamentos com o mercado e os seus potenciais públicos (Tabasso; Bracci, 2010).

No interior da linha investigativa acima clarificada, a seleção das canções que compõem a amostra da pesquisa tem respondido a um critério bem claro: a referência explícita à África. Para complementar o primeiro e mais relevante nível de análise, outros instrumentos qualitativos foram utilizados, tais como declarações, entrevistas junto a jornais nacionais principalmente dos rappers Ítalo-Africanos, postes nos seus respetivos blogues,

1 Texto original em inglês.

2 Esta expressão é a tradução literal do italiano "Musica leggera”, que significa "música popular". 
iniciativas políticas e sociais que eles têm protagonizado com vista à promoção dos seus direitos de cidadania.

Se a realidade é uma construção social (Berger; Luckmann, 1966), a imagem que a música italiana tem projetado da África não só não é unívoca, como não é unilateral. Ou melhor, o tem sido por longo tempo, coisificando a África; no entanto, os novos rappers Ítalo-Africanos têm conseguido inverter esta relação objetual.

\section{A representação da África depois da Segunda Guerra Mundial: a África como ausência}

A Itália saiu da segunda Guerra Mundial com o seu aparato produtivo, as suas infraestruturas institucionais e a sua dignidade, completamente dilacerados. Entretanto, novas correntes culturais começaram a se impor a seguir ao fim do conflito. Principalmente no cinema, o neorrealismo, com realizadores tais como Rossellini, De Sica e Visconti quiseram celebrar o heroísmo quotidiano de gente humilde (Faldini; Fofi, 1979), ao passo que a rádio e, desde 1954, a televisão pública, iniciaram a emitir muitos programas dedicados ao descobrimento, por parte do grande público, das tradições e da música populares.

A música da década de Cinquenta reproduziu a atmosfera de euforia e felicidade para o novo clima de paz, rápido desenvolvimento e bem-estar. Tratava-se de uma música de evasão, bem representada pelo Festival da canção italiana de Sanremo, iniciado em 1951, e pelo lema do famoso filme de Fellini, La dolce vita (1960).

É neste contexto que deve ser colocada a análise relativa de como a canção ligeira italiana começou a representar a África nesta altura histórica. Uma África ausente, de que a sociedade italiana pouco sabia e pouco queria saber, relacionada com o inglório passado colonial e fascista que quase todos queriam rapidamente esquecer.

Apenas uma canção "africanista" tem sido achada nos quase vinte anos que vão de 1945 até 1963. Trata-se de uma canção escrita por E.A.Mario, um compositor napolitano muito afamado, que conseguiu reciclar o seu talento depois do fim da ditadura de Mussolini. Escrita em dialeto Napolitano, “Tammuriata Nera” procura dar uma imagem verissímil duma Napoli ocupada pelos “Aliados” (1943-1945).A canção conta um fato real: uma mulher Napolitana dá à luz um menino preto; as pessoas ficam admiradas por causa de um fenómeno tão incomum. Depois de ter formulado fantasiosas hipóteses, a verdade vem à tona: no ano anterior (1944), a cidade tinha visto uma vasta presença de soldados Afro-Americanos. Certamente que um deles tinha engravidado a jovem mulher, com a lógica consequência do nascimento dum filho preto ou mulato.

O ritmo recorda as baladas populares, as palavras evocam a atmosfera de Napoli daquela altura: uma Napoli pobre, mas viva, cheia de gente fora a confabular sobre o "fato do dia". Alguém se faz à rua e anuncia gritando: "Nasceu uma criatura escura escura/e a mãe o chama gGiro/sim senhor, o chama gGiro". As letras do texto deixam entender que este não foi o único caso, e que a jovem mulher era considerada como uma prostituta: 
ela estava com medo da polícia, por isso é que estava pedindo ao seu ocasional parceiro para atuar rapidamente, como um "American espresso". A canção tem um fecho bastante triste:"A senhorita Napolitana faz um filho com os Americanos [...] e acaba entrando no bordel”. Este era o único destino possível para a protagonista da canção, numa Itália do Sul ainda fortemente moralista e fechada para qualquer tipo de experiência sexual antes do casamento, ao menos do lado das mulheres.

Simbolicamente, a África, os pretos, representam na canção, por um lado os ocupantes, portanto a força e até a violência, por outro a má-sorte, uma figura muito recorrente na cultura popular napolitana.

Fora disso, a África não existe no horizonte musical italiano. Será preciso esperar quase vinte anos para ouvir de novo uma canção que aborde Africanos e pretos. Desta vez, trata-se de uma peça muito leve e sem qualquer significado social ou político. Em 1963, Edoardo Vianello (melodia) e Carlo Rossi (letras) compõem IWatussi, interpretada porVianello.

Edoardo Vianello é um compositor romano nascido em 1938, que provavelmente primeiro lançou em Itália os "summer hits", ou seja, as canções de pura evasão e de grande sucesso de público no verão.

Como o próprio Vianello declarou, I Watussi traz inspiração dum filme que ele viu ao cinema, "As minas do Rei Salomão", com referências à tribo dos Tutsi; assim,Vianello, juntamente com Carlo Rossi, resolveram estabelecer uma ligação entre esta tribo desconhecida com uma famosa dança daquela altura (PERILLI, 2011). A dança era o "Hully Gully", oficialmente lançada em 1959 por Frank Rocco em Califórnia, e logo importada para Itália.

Vianello e Rossi decidiram dizer, na sua canção, que o Hully Gully tinha sido inventado pelos Watussi, atribuindo a eles uma improvável imagem folclórica. Os Watussi são representados apenas fisicamente, como altíssimos, a ponto de conseguirem falar aos ouvidos das girafas, os seus passos tendo o comprimento de seis metros. Nenhuma outra dimensão humana é explorada no texto da canção, a não ser a habilidade na dança da tribo.

Um tal conteúdo trivial levou a canção a um sucesso enorme. Ideologicamente ou culturalmente, a canção era insignificante, mas ela contribuiu, indiretamente, para projetar uma imagem da África e dos Africanos diferente daquela colonial-fascista. Uma imagem que não inferioriza os Africanos em comparação com os Europeus, mas que os descreve duma forma tão paradoxal que acaba chamando a atenção do público em relação a eles. 
Figura 1: Capa de E.Vianello, I Watussi (1963)

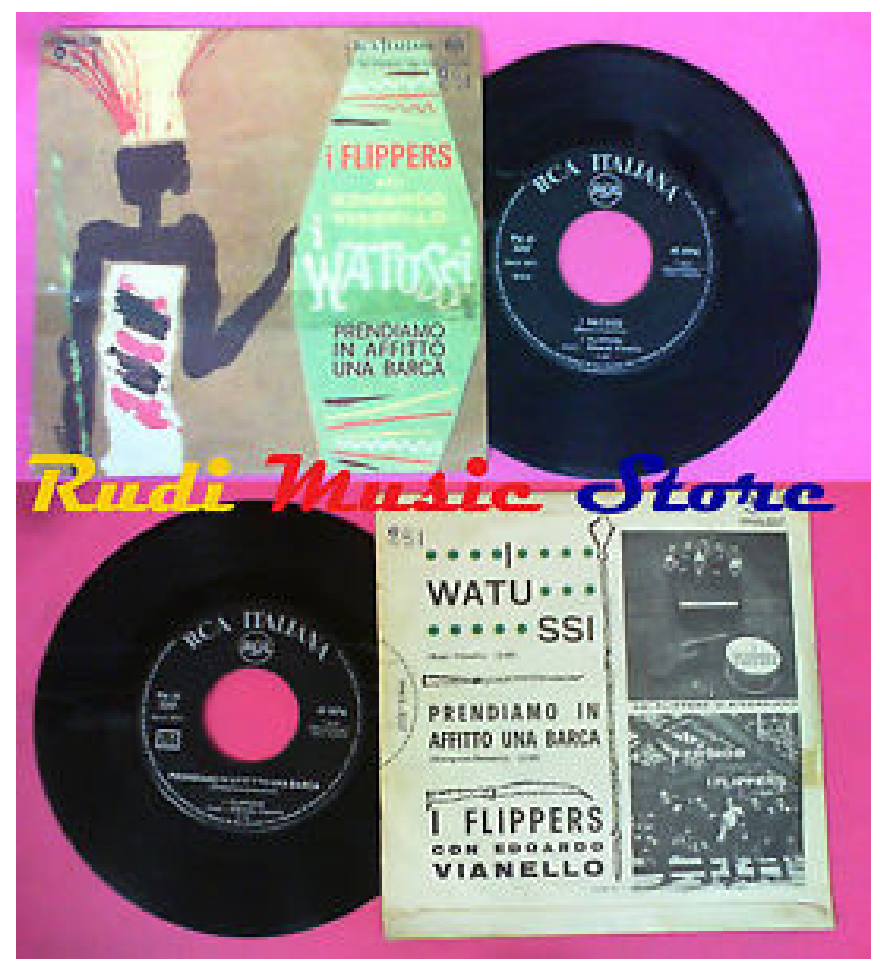

Fonte: Disponível em: <https://i.ebayimg.com/thumbs/images/g/ rWMAAOSwmtJXV ym/s-1225.jpg>. Acesso em: 15 mar. 2016.

As duas canções acima recordadas associam a África a algo de leve, físico e até simpático. Na atmosfera da "DolceVita”, a própria África entra também como elemento típico, folclórico e tranquilizador.

\section{A crise da sociedade italiana nos anos Setenta-Oitenta: a África como "abrigo" contra a civilização ocidental}

Os anos Setenta foram, na Itália, definidos como "os anos de chumbo", aludindo às muitas balas disparadas em atentados cruentos de grupos terroristas da estrema esquerda ou da estrema direita.

Foi nesse contexto que a imagem da África começou a emergir duma forma mais definida no panorama musical italiano. Mais uma vez, porém, a abordagem não foi realista: antes pelo contrário, a África tornou-se um símbolo, mas positivo: foi o ideal duma sociedade melhor, um mundo mais justo e genuíno, retomando o mito do bom selvagem e enfatizando os seus imensos e tranquilos espaços geográficos.

Compositores comprometidos com várias e diversificadas questões começaram assim a "usar" a África para contrariar hábitos e práticas da civilização ocidental. Os Albatros, por exemplo, uma banda que tinha como líder Toto Cutugno, em 1975, interpretaram uma canção intitulada "Africa", com o objetivo principal chamar a atenção em relação à questão ambiental: "Nunca poderás comparar/Este artificial mundo barulhento/Comos sons naturais/daÁfrica”. Por isso, o protagonista da canção resolve voltar para a África. 
Francesco De Gregori, provavelmente o mais refinado compositor italiano, em 1974, escreve e interpreta "Cercando un altro Egitto" ("Procurando outro Egito"). As imagens oníricas da sociedade e da história ocidentais, de que esta canção é repleta, expressam sensações fortemente negativas, mergulhando o ouvinte num verdadeiro pesadelo. Alguém que quer matar o próprio compositor, crianças que entram nos fornos crematórios Nazis, a polícia que controla a demonstração na rua: assim é representada a modernidade ocidental. Única saída é a procura dum novo continente, uma nova dimensão, com um claro paralelismo com a situação dos Judeus, "presos" em Egito e em busca de alternativas. Ainda, De Gregori utiliza a África, em 1979, com a canção "Capo d'Africa” ("Cabod'África"), parte do LP,Viva l'Italia, em que o compositor mostra uma inusual colaboração com colegas estrangeiros (Deregibus, 2003, p.115). Capo d'Africa - como o próprio De Gregori tem declarado - é um local dentro da cidade de Roma. Entretanto, este representou apenas a primeira inspiração para atingir um mundo diferente, cujo elemento central será "Uma praia tranquila, uma terra prometida".

A África como metáfora para evadir a civilização dos ruídos continua também nos anos Oitenta. A canção que melhor simboliza esta tendência é sem dúvidas "Mal d'Africa" (1983), de Franco Battiato. Inserida no LP "Orizzonti perduti" ("Horizontes perdidos"), a África acaba assumindo um papel de destaque no universo cosmológico do erudito compositor. Tudo torna-se metáfora positiva: não só o silêncio e o repouso, mas também as redes mosquiteiras, que servem de berço assim como tranquilizadores são os sons que saem da cozinha. $\mathrm{O}$ incipit é um verdadeiro manifesto da maneira de representar a África: "Depois do almoço íamos repousar/balançados pelas redes mosquiteiras e pelos ruídos da cozinha/duma janela de grades vislumbres contra o teto/e alguma coisa de abstrato tomava posse de mim". O "Mal d'Africa" de Battiato realça a nostalgia para a calma e relaxante atmosfera africana dum mundo quase que dissolvido nas recordações, mas em que o cantor está completamente mergulhado, despertando nele a sensação duma nova harmonia com a natureza e a dimensão onírica.

A representação da África como símbolo físico e geográfico de libertação e fuga da civilização ocidental quase que desaparece com o início dos anos Oitenta. Uma das raras exceções é Mango que, em 2004, escreve e interpreta "Ti porto in Africa" "Te levo para África"); entretanto, entre os anos Oitenta e Noventa, a África deixa de ser algo de longínquo e desejável para a sociedade italiana, tornando-se sujeito cada vez mais presente no país, principalmente por causa do fluxo migratório que induz a problematizar a "questão africana". O realismo substitui o simbolismo nas modalidades de representação dos compositores italianos.

\section{Da África como metáfora à África como realidade (1980s-2000s)}

Aproximadamente a partir da segunda metade dos anos Oitenta, a música popular italiana começou a representar a África duma forma diferente da mostrada no ponto 
anterior. A imigração proveniente do Sul (e do Leste) do mundo assumiu contornos claramente definidos, e vários compositores desempenharam um importante papel de denúncia e sensibilização deste novo fenómeno. Nos finais da década de Oitenta, a Itália contava com cerca de meio milhão de imigrados, número destinado a crescer rapidamente e constantemente nos anos a seguir.

Mais uma vez, foi Francesco De Gregori que, em 1987, propôs ao público italiano um insólito sujeito: "Nero" ("Preto"). A estação da representação realista já tinha começado, evidente efeito dum processo de globalização que obrigava a provinciana sociedade italiana a uma mudança no processo de coisificação da África e dos Africanos.

O "Nero" é uma vítima desta globalização, alguém que resolve emigrar, "da periferia do mundo àquela duma cidade", de maneira ilegal, perdendo qualquer dignidade humana. O "Nero" "sabe", como as letras repetem por várias vezes; o que a vida é, a sua dureza, as suas enormes dificuldades num mundo completamente desconhecido. Mas este "ser pensante" é reduzido a um objeto por parte das instituições e das pessoas italianas. E De Gregori recorda como este objeto sem direitos é tratado: "pontapeado pela Policia, acorrentado a um comboio com um mandado de expulsão, ou usado para acender uma fogueira". O fecho da canção apresenta uma imagem lírica: este preto sofria sim duma doença, mas uma doença não física: ele sofria de falta de amor.

Em 2005, De Gregori escreve outra canção, "Vai in Africa Celestino" ("Vai para África Celestino"), em que a vida moderna é descrita, sobretudo em relação aos pobres, como algo que provoca o desnorteamento. A representação dos imigrados entra neste contexto mais geral, associando assim migração com fome, tristeza, desespero. Como De Gregori confirma, o uso da figura do CelestinoV (Papa citado por Dante na Divina Comédia) constitui um pretexto, "mas a canção é atual, para as vítimas do processo de empobrecimento global, e para nós todos; nós somos vítimas ouassassinos, nunca neutrais!" (Micocci, 2005).

Poucos anos depois do "Nero", outro afamado compositor, o Napolitano Pino Daniele, escreve (1991) “O’Scarrafone”.Título em dialeto napolitano, letras numa língua mista Napolitano-Italiano,esta canção representa um hino à diversidade, a partir da experiência da migração. Daniele enfatiza as diferenças culturais entre os meridionais e os setentrionais da Itália, com explícitas críticas ao partido da Liga do Norte, portador naquela altura de tendências separatistas e até certo ponto racistas. $O$ refrão da canção revela o relativismo com que o compositor convida a olhar para os "outros": "Cada scarrafone [palavra napolitana intraduzível, mas que significa feio e repugnante] é achado bonito pela sua própria mãe”.

Os compositores mencionados iniciam uma profunda revisão nas modalidades de representação da África: os Africanos agora estão dentro de casa. E, representando a eles, acabam por destacar a postura dos Italianos para com os Africanos. O resultado é, se não uma inversão objetual completa, pelo menos um mecanismo de reciprocidade.

Nessa senda, novas bandas e diferentes estilos musicais emergem. E a África ganha espaço na esfera pública italiana.

Os "Africa unite" (primeiro nome "Africa united"), primeira banda reggae italiana, constituída em Pinerolo (Turim, 1981), depois da morte de Bob Marley, expressa um claro 
comprometimento político, professando ideais de revolução social da esquerda mais radical. "Alba meticcia" ("Madrugada mestiça”, 1995) constitui provavelmente a primeira canção que pauta pelo melting pot. Inserida no LP "Un sole che brucia" ("Um sol que queima”), esta peça defende a contaminação entre pessoas de diferentes culturas e cores, com uma simples mas significativa referência à história italiana. A "raça" italiana resulta duma miscigenação entre "Checos e Turcos com Normandos e Hispânicos/Árabes e Judeus Gregos Eslavos Africanos", concluindo com a frase: "de puro só o coração para o mundo de/amanhã".

$\mathrm{Na}$ mesma altura outra banda faz o seu ingresso na música italiana: os "Modena City Ramblers" (da cidade de Modena) que, em 1994 e em 2004 apresentam provavelmente as duas canções símbolo da representação dos imigrados africanos na Itália. Trata-se de "Ahmed l'ambulante" ("Ahmed oambulante") e "Ebano" ("Pão preto"). A primeira traz inspiração dum poema de Stefano Benni e é escrita na primeira pessoa. O falecido Ahmed fala do céu, expressando a sua satisfação por não ter morrido "no frio das vossas cidades", agradecendo Ashiwa, "a deusa da Noite", desconhecida aos Italianos, que permitiu que o seu povo cantasse e dançasse por 40 noites, recordando ele.

"Ahmed l'ambulante" obteve um bom sucesso. Naquela altura, a canção despertou os Italianos, seguros de que xenofobia, racismo e exclusão dos imigrados não faziam parte da sua bagagem cultural. Os Modena City Ramblers foram capazes de propor uma representação da África diferente. Um pacato e modesto africano emigrado na Itália era visto como superior, quer do ponto de vista ético, quer religioso, relativamente aos civilizados Italianos.

Com "Ebano" (2004), este grupo aborda a desbordante prostituição sobretudo nigeriana nas ruas italianas. A narrativa centra-se na história pessoal da lindíssima "Perla Nera" ("Pérola Preta"). Com apenas 16 anos, ela foi vendida e levada para a cidade, onde os seus sonhos transformaram-se em pesadelos. Mas ela foi suficientemente experta para guardar dinheiro para ir para Itália, nomeadamente em Palermo (Sićlia). Aqui, começou como recolhedora de laranjas e limões em troca dum salário muito modesto. Resolveu depois ir para o Norte, a Bolonha, onde tornou-se prostituta, "e todas as pessoas sabem que a Pérola Preta distribui felicidade em troca de dinheiro".

Mais uma vez, o bom sucesso da canção sacudiu a sociedade italiana, que continuava a não querer ver o drama dessas mulheres, enfrentando o fenómeno apenas como questão de ordem pública ou de moral.

Outros grupos quiseram abordar temáticas relacionadas com a emigração Africana: desde o trabalho ilegal aos limites da exploração esclavagista (é o caso dos Bisca que, em 1994, interpretam "Tammuriata del lavoro nero" ("Tammuriata do trabalho preto"), ou da mais famosa "Banda Bassotti" que, em 1992, lança o LP "Figli della stessa rabbia" "Filhos da mesma raiva"), que tem a peça "La rotta degli schiavi" ("A rota dos escravos") mais ligada à África. 
Figura 2: Capa de Banda Bassotti, Figli della stessa rabbia (1992)

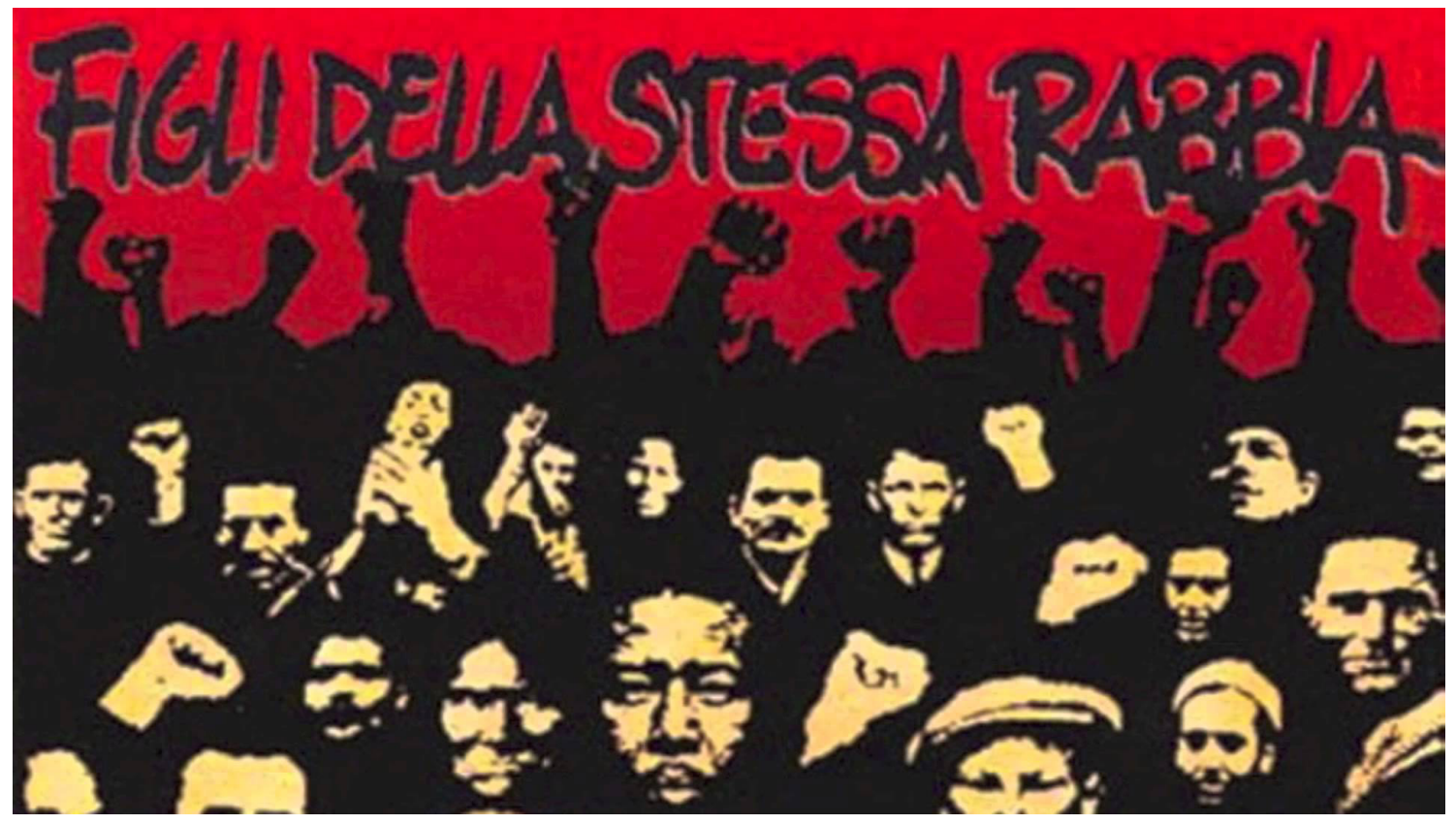

Fonte: Disponível em: < https://i.ytimg.com/vi/uPxjv48ZLbU/ maxresdefault.jpg >. Acesso em: 15 mar. 2016.

Os versos são muito contundentes e até provocatórios: "Come todos os brancos/ Maldosos como o rei/ Come também os racistas e os exploradores/Será uma boa dieta/ Pela terra”. Essas letras, desprovidas de qualquer retórica, se tornarão um hino clássico de redenção da memória, história e justiça universal. "La rotta degli schiavi" representa um ponto firme, no contexto da música italiana, para o posicionamento radical e esquerdista a respeito do racismo, intolerância e exploração do estrangeiro.

\section{Uma nova estação: a África como sujeito (desde 2000 até hoje)}

Apesar da evolução musical assinalada no ponto anterior, a África continuava a ser um objeto: já não representada duma forma puramente simbólica, como aconteceu nos anos Oitenta, mas ainda sem um protagonismo subjetivo capaz de expressar um ponto de vista autenticamente interno. A África ainda não tem voz ativa até aproximadamente a década de Dois mil.

Foi nessa altura que compositores e rappers Italo-Africanos emergiram da cultura juvenil e urbana das grandes metrópoles italianas: e serão eles a conseguir reverter o relacionamento objeto-sujeito acerca da África e dos Africanos, criando um espaço de debate até então desconhecido na esfera pública italiana.

O cenário demográfico empurra para que a transição ocorra: em 2011 havia, na Itália, 4,5 milhões de imigrados, correspondentes a cerca de $8 \%$ do total da população residente (em 2015 a percentagem é de 8,3\%). A qualidade da migração também sofreu significativas alterações. A segunda geração de filhos de migrantes nascidos e educados na Itália começou a pôr questões de fundo em termos de acesso à cidadania, reclamando 
iguais condições com os seus colegas e amigos com quem eram crescidos. No mundo da Mídias, a maioria dos órgãos de comunicação social sofreu uma crise notável. Exatamente o contrário deve ser dito para a Mídia "étnica”, que estava presente, em 2010, eram mais de 150 no território nacional: 65 jornais, 59 emissoras radiofónicas, 24 televisões. Cerca de 1 milhão de leitores por mês e mil jornalistas (ou locutores) cruzam-se diariamente nos órgãos de comunicação social geridos por estrangeiros residentes em plataformas on-line. $\mathrm{O}$ network <www.stranieriinitalia.it> (fundado em 2001) recebe cerca de 400 mil visitas por mês (Fiorentini, 2005; Custovic, 2010).A África entrou a pleno título na vida italiana como protagonista ativa e atenta aos vários aspetos de interesse nacional. Uma nova subjetividade, talvez uma nova subcultura tem-se formado graças às segundas gerações. O mundo musical não podia ficar imune desse poderoso fenómeno que mexe com identidades culturais e coletivas. Por isso, neste ponto, serão apresentadas as principais formas e caraterísticas com que os Ítalo-Africanos representam a si próprios e a realidade em que vivem, sem negligenciar textos de autores italianos também comprometidos com a "questão africana".

A segunda geração de imigrados tem enveredado relevantes esforços no sentido de formar uma rede que, embora deixando autonomia completa a cada artista, tem havido a capacidade de apresentar-se como um conjunto orgânico e bem organizado diante da opinião pública e as próprias instituições. Em 2005, esta rede se constitui formalmente, mediante a associação G2 (<www.secondegenerazioni.it/>).

Embora diversificados quanto aos estilos musicais, aquilo que prevalece é a adesão ao rap no sentido musical, e à cultura hip-hop no sentido mais geral e identitário. É possível afirmar que se trata do cruzamento de pelo menos três subculturas: a juvenil-urbana, a do hip-hop e a dos mestiços italianos, que encontram uma feliz síntese no G2.

Não se quer entrar aqui no tratamento da cultura hip-hop e das suas origens, uma vez que existe hoje uma abundante literatura (Shaw, 1986; Rose, 1994; Blanchard, 1999; Gilroy, 2000; Mitchell, 2001; Kitwana, 2002).

Pelo contrário, vale a pena assinalar que o hip-hop entra na vida dos jovens das grandes cidades por volta dos anos Oitenta. A sua primeira caraterística é que se trata de uma comunidade dividida em termos de princípios, ideais e opiniões políticas, tendo, como elemento comum, apenas a forma artística genericamente expressa através do guarda-chuva do rap (Ivic, 2010). No caso italiano é possível falar de "comunidade hip-hop", mais do que de "cultura hip-hop".

A "Old School" do hip-hop italiano procurou se inspirar em "Zulu Nation". Foi nos finais dos anos Oitenta, com a incipiente crise do comunismo, que muitas bandas (Posse) começaram a expressar a sua ideologia radical de esquerda mediante o rap, formando um circuito informal, mas bem organizado, os Centros Sociais Ocupados Autogeridos (CSOA). Onda Rossa Posse é provavelmente o exemplo melhor desta tendência (Fascina, 2015).

A primeira compilation do rap italiano, Italian Rap Attack (Irma Records) foi editada em 1992, graças à iniciativa de Luca De Gennaro. Nessa altura a "Old School” desaparece, em prol duma geração mais recente de bandas, entre 1993 e 1994, quando Sangue Misto lançao seu primeiro LP, $S+M$ (1994), conseguindo um bom sucesso. Em 1996 o LP dos 
Articolo 31, Messa di vespiri, ultrapassa as 100 mil cópias vendidas. A música rap e a cultura hip-hop começaram a serem conhecidas pelo grande público e consumidas numa dimensão muito mais coletiva do que individual (Ferrari, 2000).

Entre os sujeitos mais abordados por essas bandas e pelo próprio Jovanotti, o "rei" do rap italiano, antirracismo, integração e relações com a África assumem uma relevância especial.Almanegretta, uma banda de Napoli, representa talvez o exemplo melhor quanto à penetração de valores como a interculturalidade, a tolerância e a "Africanidade". Em particular, Almanegretta redefine "a identidade do Sul da Itália mediante uma memória coletiva que conecta o sangue italiano com o africano" (Fascina, 2015). Em Figli di Annibale (Filhos de Aníbal, 1992), a ideia é que os Italianos possuem sangue preto graças ao General Aníbal, que derrotou os Romanos e reinou na Itália durante 15 ou 20 anos.

Os primeiros rappers Ítalo-Africanos e Ítalo-Asiáticos vivem, crescem, estudam no meio cultural urbano das grandes cidades, sobretudo Roma e as metrópoles do Norte (Milão, Turim, Bolonha), em contato constante com os rappers italianos e a cultura hip-hop, que aparece como possibilidade de resgate das suas vidas complicadas.

Mas quem são os representantes duma tendência inédita da música popular italiana? Donde é que eles vêm? Quais os seus anseios, ideias, sonhos? E qual o tipo de música que praticam e as mensagens que divulgam?

Para responder a essas perguntas, a metodologia melhor é procurar desenhar breves retratos biográficos e musicais de alguns deles. Tal opção deriva da convicção que as suas condições de existência e as suas complexas identidades jogaram um papel decisivo na escolha do estilo musical privilegiado (rap mesclado com ritmos africanos), assim como nas temáticas mais abordadas (antirracismo, multiculturalismo, obtenção da nacionalidade italiana por parte das segundas gerações), dando origem a uma reviravolta completa da representação da África na música italiana.Associado a essa análise biográfica está um breve exame dos textos que estes compositores propõem, de maneira a mostrar as inovações por eles trazidos, incluindo a criação da rede G2.

\subsection{A África como sujeito nas canções dos rappers Ítalo-Africanos}

Com a entrada dos rappers de origem Ítalo-Africana, o cenário musical nacional muda por completo; e sobretudo muda a maneira de representar a África e os imigrados africanos. Com efeito, a África adquire uma nova e inédita subjetividade, ela é representada de acordo com pontos de vista internos, de quem vive e experiencia diariamente o que significa ser Africano num país como a Itália, de quem tem provado na sua pele a exclusão, a marginalização, até o racismo, implícito ou aberto que seja. E procura um resgate, um reconhecimento, certo de que os seus meios intelectuais e culturais não são inferiores aos dos Italianos “de gema”. Mas este grupo vai além da simples autorrepresentação: a pretensão de quem está para oferecer uma ideia própria da sociedade italiana, dos seus preconceitos, da sua dimensão ainda muito provincial e pouco cosmopolita.

A música, nomeadamente o rap, constitui para este grupo de cantores uma forma de resgate social, mas também cultural e individual. A sua força está na potência das mensa- 
gens comunicadas, na capacidade musical de experimentação rítmica, melódica, linguística, diante dum panorama nacional ainda fechado, sacudido dum furacão proveniente do interior do país, mas de que quase ninguém se tinha percebido. Os três solistas escolhidos são Amir Issaa,Valentino Ag e Karima.

O mais destacado deste grupo é Amir Issaa. Nascido em Roma em 1978 de pai egípcio e muçulmano e de mãe italiana e católica, atravessou várias dificuldades ao longo da infância. O pai era preso continuamente, como recorda uma das suas canções, (" 5 de manhã"). Amir se autodefine como sendo completamente leigo (Laffranchi, 2006), tendo crescido num dos mais populosos bairros da capital, Torpignattara, até a entrada no mundo do rap nos anos Noventa, ainda muito novo. Em 1996 constituiu a banda "Zoo di Roma", de inspiração hip-hop. O primeiro grande sucesso foi em 2011, quando escreveu e interpretou a coluna sonora do filme "Scialla!" (“Estejas em paz!”), realizado por Francesco Bruni. A canção (que leva o mesmo título que o filme) foi galardoada como ganhadora do Premio Cinema Giovane 2012 - Special Award of the Artistic Direction, com uma nomeação para o David de Donatello 2012. Amir Issaa é hoje um símbolo da "segunda geração". Tem sido entrevistado pelos principais jornais italianos, tais como "Il Corriere della Sera", "La Repubblica", "Il Fatto Quotidiano", "Il Messaggero", "Libero" e muitos outros. Recebeu o convite da Raiuno (o principal canal da TV pública italiana) para participar no programa matutino "Faça a coisa certa", no dia 8 de Janeiro de 2013. Até a imprensa estrangeira interessou-se por ele. "The Guardian" (21/01/2013) escreveu um artigo, recordando o seu empenho para a mudança da lei italiana sobre a nacionalidade em prol do ius soli (WA:2013), conseguindo também uma menção especial por parte da UNICEF.

Amir desenvolveu uma autónoma ideia da música e da sua função, quer do ponto de vista subjetivo, quer em termos sociais."Mediante a música - afirma Amir - sempre tenho procurado transmitir uma mensagem positiva. Minha história pessoal não é simples, com meu pai preso. Porém procurei não dar tudo por perdido" (BASSAN, 2012). Se a música tem sido, para ele, um meio de redempção, a arte deveria representar um guia para os mais jovens: "Através das minhas canções,tento sensibilizar a malta [...]. Neste sentido, sim, tenho-me sentido um guia para alguém”. A função da música é dupla: manda mensagens para fora, mas serve também como um meio interior de purificação: “A música tem-me feito estar bem. Consegui expulsar um peso que eu tinha há muito tempo, tem sido como uma espécie de autotratamento" (Bassan, 2012, on-line). A escolha para o rap é também bem motivada por parte de Issaa: o rap mete todas as pessoas ao mesmo nível, é profundamente democrático. Como recorda, "Havia jovens cujos pais eram embaixadores, outros, como eu, cujo pai estava na cadeia. Mas a músicanos ajudou a não guetizar a nós próprios, éramos todos iguais diante do rap" (Bassan, 2012, on-line). E vai ainda mais longe, afirmando: "Não sei quanto um miúdo de 15 ou 16 anos pode identificar-secom as letras das canções de Ligabue, Vasco Rossi ou Eros Ramazzotti [...] pelo contrário, o rap diz a verdade" (Bassan, 2012, on-line).

Além dessa função libertadora e reveladora das verdades individuais e sociais, a música, para Amir Issaa, é também um meio para travar lutas especificamente focadas nos 
direitos da segunda geração. Fez pressão para a mudança em Parlamento da lei sobre a nacionalidade; em 2012, produziu um vídeo-apelo dirigido ao então Chefe de Estado, Giorgio Napolitano, tendo sido convidado pela Câmara dos Deputados (um dos dois ramos do Parlamento italiano) sobre o assunto; finalmente, escreveu uma carta ao atual Chefe de Estado, Mattarella, que tornou-se petição; juntamente com Karima, a outra embaixadora no Arezzo Wave Ius Soli, fez a mesma coisa solicitando o atual Primeiro- Ministro, Matteo Renzi, para obterum compromisso sério, por parte do Parlamento, ainda no sentido de mudar a lei sobre a nacionalidade italiana (Suraci, 2015).

A essa intensa atividade de sensibilização política, Amir juntou um trabalho de tipo mais cultural e educativo: foi ele que, em 2014, fechou o ano escolar na escola Pisacane de Roma, onde 97\% dos estudantes são filhos de imigrados ou "mistos", como parte dum projeto pela promoção do multiculturalismo em mais de 100 escolas italianas, denominado "Poder às Palavras".

A crítica italiana já tem feito dele uma figura de destaque da nova tendência musical rap. "Antes mesmo de se tornar famoso, ele já era um símbolo" (Laffranchi, 2006, on-line), representado como "uma influente voz do hip-hop italiano, um combatente que tem conseguido um duro percurso de resistência diante dos muitos preconceitos que afetam a segunda geração" (Pagano, 2015).

A sua música, sempre ao ritmo do rap, aborda vários assuntos, essencialmente focados na condição dos imigrados africanos na Itália, na necessidade de promover uma postura tolerante e multicultural e na adoção do Ius soli. O tema provavelmente mais presente é o da identidade nacional. Amir, assim como quase todos os seus colegas da G2, procuram distinguir-se dos outros imigrados da primeira geração.

O seu primeiro sucesso foi, em 2006, "Straniero nella mia nazione” ("Estrangeiro na minha nação"). Cantada alternando língua italiana com dialeto romano, essa canção representa uma espécie de "bilhete de identidade artístico" de Issaa. O balanço que ele faz é, no geral, negativo: "Me chamam estrangeiro no sítio em que eu sempre vivi". Issaa desafia os "outros" (ou seja, os Italianos "puros") não tanto invocando piedade, solidariedade, amizade, mas uma aberta competição: "Quero ser rico como o presidente", embora, até o momento, declara-se "orgulhoso do meu nome e do meu sangue mestiço/agora isso é suficiente para me sentir como o mais rico".

A canção que ainda mais deu de falar foi "Iusmusic" (2014). Linguagem muito agressiva e até insultuosa, o sujeito não difere muito do abordado em "Straniero nella mia nazione", :mas desta vez com mais consciência e raiva, e um apelo final à união nacional. Os Italianos com postura racista ou intolerante são definidos como "pessoas estúpidas, ainda a viver na Idade Média". Issaa desafia esses indivíduos no puro terreno da competitividade, anunciando: "E se o futuro é nosso,o queremos em exclusivo". Um futuro marcado por um presente ainda injusto e ilógico: "A minha não é uma raça, é uma tribo [...] o meu pessoal está cansado de ser acusadode ser consideradoo perigo dentro de casa". A canção se conclui com uma imagem chamativa sobre o relacionamento entre um imigrado com formação superior e um polícia:"Amigo graduado mandado parar por um 
cara que só tem a oitava classe humilhado e abusado" por causa da cor da sua pele ou do seu nome. Finalmente, Issaa convida os Italianos "puros" a refletir sobre o seu destino comum, pelo que é estúpido fazer distinções de outra natureza. Partilham "a mesma línguaa mesma raiva a mesma comida, somos na mesma merda eu não sou o vosso inimigo". São todos “Irmãos da Itália”, procurando um motivo de união no futebol: "Balotelli marca golo e todos são felizes".

As reações a essa canção não demoraram. O seu conteúdo tem sido interpretado consoante vários pontos de vista, todos eles de tipo político: os partidos da direita e uma boa parte da imprensa a eles ligada expressaram a convicção de estar diante duma verdadeira instigação ao "racismo ao contrário", contra os Italianos "puros". O pior foi que Issaa convidou um deputado de origem marroquina do PD, Khalid Chaouki, para recitar no vídeo, acentuando a polémica política. Como reação, os senadores de "Forza Italia" (o partido de Berlusconi), nomeadamente Gasparri, pediram para abrir um inquérito, ao passo que a Liga do Norte exigiu as demissões imediatas de Chaouki (POLCHI, 2014). A imprensa simpatizante da direita alimentou o debate: "Libero" observou: "A aparência é de algo de que não estás à espera. Pelo menos não num vídeo-clip dum rapper que parece falar de racismo ao contrário" (Osmetti, 2014). "Il Giornale" procurou ir mais além, generalizando: "é impossível não reconhecer o fil rouge que liga tantos jihadistas a esta expressão musical [o rap]", associando o leigo Issaa ao "rap islamita" (Giordano, 2015). Diante dessas críticas, Issaa teve que explicar duma forma pública o seu posicionamento e a sua italianidade: "Minha mãe era italiana [...] e se eu tivesse que ir para o Egipto, não saberia para onde começar [...] Não sou muçulmano”. E, relativamente às letras da canção: "No vídeo tem maravilhosas crianças que estão crescendo aqui e eles já são o futuro da Itália, eles são funs de Totti e alguns deles mal falam as línguas do país de origem dos seus pais. Mas estamos a falar de quê?” (Polchi, 2014).

Figura 3: Capa de Amir Issaa, Iusmusic (2014)

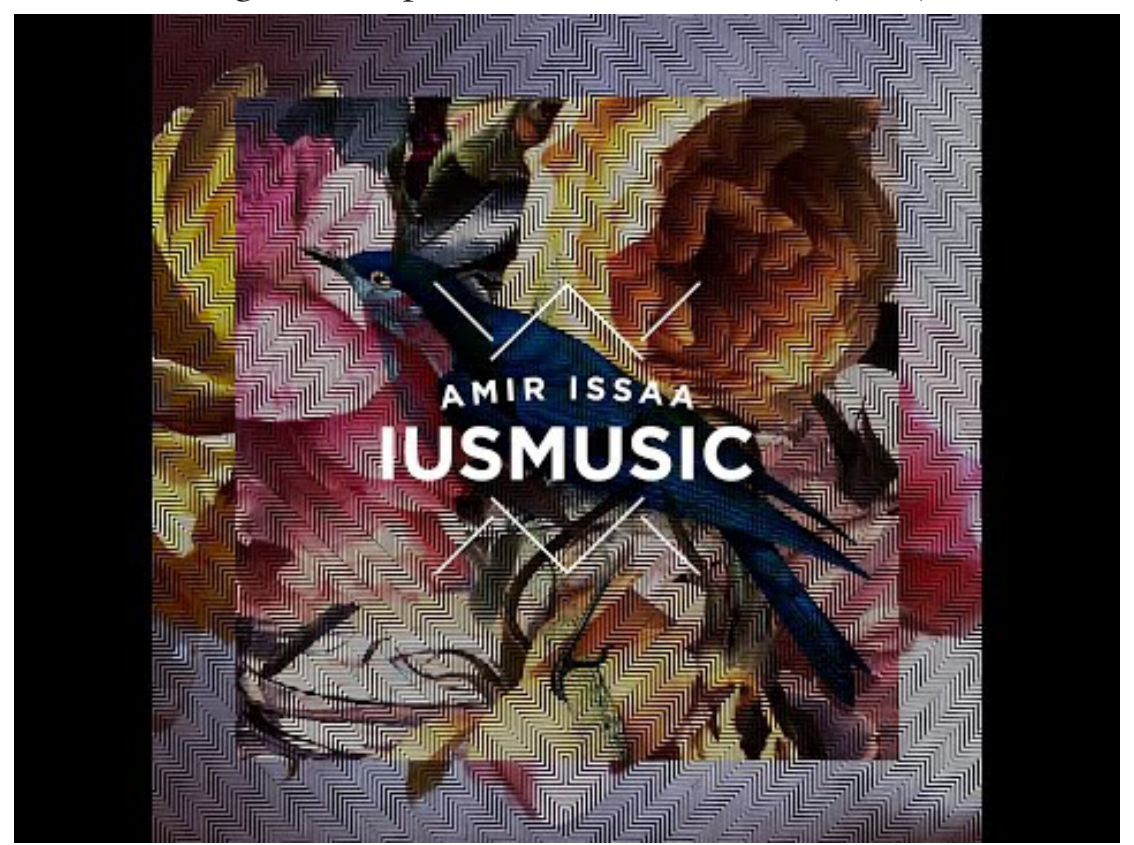

Fonte: Disponível em: <goo.gl/4dXoX2>. Acesso em: 14 mar. 2016. 
Uma segunda figura representativa do rap Ítalo-Africano é Valentino Ag, nome completo Onierhovwo Valentino Agunu, 28 anos, nascido em Romade, de pais nigerianos. A sua canção mais famosa, "Sono nato qui", "Nasci aqui", é a coluna sonora do documentário "18 IUS Soli”, realizado por Fred Kuwornu. As suas referências musicais são os rappers italianos Fabri Fibra e Marracash, além das tradições e dos ritmos africanos. Apesar de os pais terem mudado para os Estados Unidos, a sua luta para o Ius soli e, consequentemente, a obtenção da cidadania italiana continua. Tem declarado que "Me sinto 100\% italiano. Além disso, eu carrego o legado das minhas origens nigerianas: língua, alimentação, música. E o respeito para os mais velhos" (Ahmed, 2012).

Em termos temáticos, "Sono nato qui" partilha a mesma abordagem que as canções de Issaa. Roberto Saviano, um dos mais destacados escritores e colunistas nacionais, colocou o vídeo da canção no seu site do Facebook, conseguindo mais de mil visualizações e muitos comentários, alguns negativos. A canção é concebida através do diálogo com um rapaz italiano, realçando a surpresa para o cantor ao não ser ainda considerado cidadão, apesar do seu pronunciado sotaque romano. A sua italianidade está fora de qualquer dúvida, a sua exclusão jurídica fora de qualquer racional compreensão: "Cresci pasta manteiga e parmesão". Assim, a única diferença com os outros Italianos é que "Nasci aqui mas levo de lá as minhas raízes de vida dentro de mim”. Se alguém me quiser excluir, o problema, ele diz, é dele, não meu, lançando uma provocação linguística: "Me dizes parabéns tu falas bem minha língua mas sou eu que a ensino a ti antes de ela se extinguir".

Finalmente, Karima, nome completo Annie Karima Genhyei, nascida em Roma em 1980, de pais liberianos, começa a sua carreira artística como dançarina, para passar depois a ser vocalista nas mais famosas discotecas italianas. Colabora com o network $\mathrm{M} 2 \mathrm{O}$ (TV, rádio, site), tornando-se uma das suas vozes oficiais. Em 2010, juntamente com o DJ/Producer Cukiman, funda o duo Pepe Soup, mesclando vários ritmos africanos; logo a seguir os dois dão origem à etiqueta discográfica Soupu Music, juntando bass inglês com ritmos da África ocidental. Em 2013 resolve voltar para Monróvia, onde dirige, em 2013, um orfanotrófio, para regressar a Itália em 2014, altura em que faz o seu debuto como solista. O álbum é $2 \mathrm{G}$, editado pela Soupu Music, que expressa uma enorme força polémica assim como a tentativa de experimentação musical. Rap, bass, ritmos da África ocidental constituem o pano de fundo sonoro deste primeiro trabalho à sola da Karima. Linguisticamente, todas as canções são construídas usando o Pidgin English, uma espécie de inglês crioulizado por parte das populações anglófonas da África ocidental, inclusive Libéria. A inspiração de polémica política é claramente reconhecível nas duas canções mais famosas, "Orangutan" e "Bunga Bunga”. A primeira expressa a raiva contra o antigo Ministro das Reformas do último Governo-Berlusconi, Roberto Calderoli, da Liga do Norte. Quando o Primeiro Ministro do novo Governo de centro-esquerda, Enrico Letta, nomeou Cécil Kyenge, representante do PD e Ítalo-Congolês, como Ministro da Coesão Social, Calderoli a chamou de "Orangutan". A canção - notou um crítico musical - foi uma verdadeira "palmada" contra este homem político, e deu notoriedade à Karima. (Sanzone, 2014). A própria compositora define "Orangutan" como um "cornerstone" da 
sua carreira (THE Black Blog, n.d.). "Bunga Bunga" evoca as festas de tipo sexual que o antigo Primeiro Ministro italiano, Berlusconi, costumava organizar, e que ele próprio, usando uma linguagem confidencial, definiu de "Bunga-Bunga". No complexo, a primeira compilação da Karima teve um ótimo sucesso: no seio dum programa de libertação social e racial, "é indicativo do nosso estado atual, na qualidade do movimento musical, que tenha sido uma artista como Karima a mostrar aos diversos colegas seus a via da experimentação musical" (Nicastro, s.d.).

Em 2015, Karima lança uma segunda obra, Bantu Juke, mais uma vez centrada na denúncia das práticas "mais do que duvidosa, sobre a migração [...] de seu país, a Itália."3 (Aodren, 2015, tradução nossa).

Não há dúvidas de que Karima expressa duma forma agressiva a afirmação duma dignidade feminina e africana na Itália e na Europa, derivante de experiências pessoais, assim como coletivas. Elementos biográficos duma vida difícil se juntam com a luta pelo reconhecimento do Ius soli, princípio fundador do novo direito de cidadania italiano. "Tinha seis anos quando fui chamada pela primeira vez negra, nove quando respondi aos insultos e treze quando começaram as primeiras agressões dos colegas de escola", confessa numa entrevista (Sanzone, 2014, on-line). Esta cantora expressa a sua subjetividade mediante um grito de protesto, aberto e claro "contra um país que não reconhece como italianos os que nascem aqui de famílias estrangeiras" (Sanzone, 2014, on-line), mas procurando sempre a sua unicidade como ser humano e artista. Duma forma muito consciente, declara:"Eu pertenço e represento este resultado"4 (The Black Blog, s.d., tradução nossa). Como para o caso de Issaa, para Karima também a música representa uma via de salvação, expressão, purificação, mediante a qual tornar público o racismo presente na Itália contra os imigrados, principalmente africanos (Sefa-Boakye, 2014).

Figura 4: Capa de Karima, Orangutan (2014).

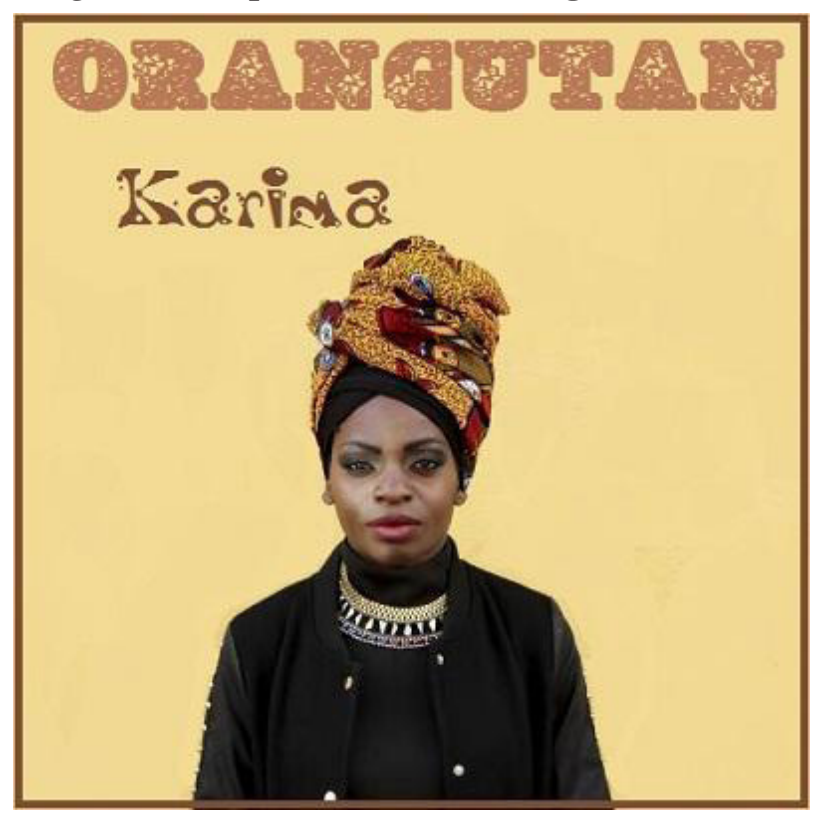

3 Texto original em francês.

4 Texto original em inglês. 


\section{$4.2 \mathrm{O}$ projeto $\ll \mathrm{G} 2 »$}

A nova geração de rappers Ítalo-Africanos não deve ser considerada e analisada apenas em razão das individualidades artísticas que dela fazem parte. Diferentemente daquilo que tem normalmente acontecido com os cantores e compositores italianos, acentuadamente individualistas, o interesse em travar uma luta comum fez com que estes artistas se juntassem, criando um network que hoje em dia já constitui uma referência obrigatória no panorama musical nacional.

A “Rede G2" constitui-se em 2005; seus objetivos fundamentais são a promoção da imagem dos seus membros como cidadãos italianos, o diálogo intercultural e a ação de lobby para com o Parlamento italiano para mudar a lei sobre a cidadania, no sentido de privilegiar o princípio do Ius soli, em detrimento do Ius sanguinis.

As atividades levadas a cabo são várias e diferenciadas: o site, a página de Facebook, uma relevante produção musical, livros, filmes, uma fotonovela etc. O método de trabalho está virado para enaltecer o elemento coletivo, promovendo campanhas de tipo político, cultural e educacional (Sonko, 2009). O acesso aos principais órgãos de comunicação social tem sido constantee significativo, apesar das enormes dificuldades iniciais: alguém tem falado deles como das verdadeiras vítimas do prejuízo italiano, que tem "demonizado a eles como um perigo para a sociedade italiana" (Goonan, 2009, p. 2).

Os seus interesses principais não estão focados no fenómeno da imigração no geral, mas sim nas questões da "segunda geração", tendo como maior questão a obtenção da nacionalidade italiana. Mesmo se a Rede autodefine como "política mas não partidária", a suainclinação é claramente esquerdista. O símbolo dessa rede é o documentário "18 IUS Soli", realizado por Fred Kuwornu, e o CD "Stranieri a chi” "“Estrangeiros a quem”).

Composto por 13 canções escritas e interpretadas por 13 diferentes rappers da segunda geração, mais um remake do hit de Lucio Battisti, "Con il nastro rosa”, interpretado por Wahid Efendi, vale a pena recordar, entre os cantores, Zanko el Arabe Blanco, Natural Disastro, Mike Samaniego e outros. As canções trazem uma mensagem unívoca: o reconhecimento dos autores como Italianos, mediante a adoção do Ius soli (FABIANI, 2008). Nessa perspetiva, a segunda geração pretende se distinguir claramente do resto dos imigrados, a partir dos seus respetivos pais. O "manifesto" do CD e da própria rede pode ser considerado o seguinte "Não importa se vocês pensam que eu sou um imigrado, ao final o é meu pai, sabes já estou acostumado a isso, inclusive falo em dialeto. Nasci neste Estado, eu também estudei, conheço a cultura, esta língua e tenho razão só vos peço direitos mas nenhuma distinção", fala de Mike Samaniego (FABIANI, 2008, on-line).

Como assinalado a propósito de Issaa e de Karima, os membros da rede trouxeram significativas inovações no cenário musical italiano: se, por um lado, eles conseguiram renovar a tradição dum rap comprometido socialmente e politicamente, tendo como referências principais Fabri Fibra, Marracash, Clementino Caparezza, Neffa,o uso da linguagem é absolutamente novo: com efeito, eles misturam o idioma italiano com diversas variantes dialetais (especialmente o Romano) e com as suas línguas familiares, como Ára- 
be, Pidgin English, Francês etc.; o estilo musical também resulta de interessantes contaminações, que fazem desta rede um dos locais italianos mais abertos à experimentaçãoartística, buscando influências e ritmos da Nigéria, Libéria, Síria, Egipto, Moçambique, assim como do Japão, América Latina e Estados Unidos. O melhor exemplo talvez possa ser identificado no compositor Lama Islam, nascido no Marrocos e emigrado na Itália com dez anos. Depois de alguns anos como solista, resolveu formar uma banda, Mic Meskin, composta por Italianos, Marroquinos e Senegaleses, abrindo o primeiro hip-hop store na Itália (nomeadamente em Bolonha).

\subsection{A representação da África fora da Rede G2: entre continuidade e inovações}

Neste ponto mostrar-se-ão as principais linhas musicais em volta da "questão africana", fora do consistente grupo de rappers da Rede G2. Para fazer isso, a subdivisão usada será de tipo temático, distinguindo três grandes âmbitos: a viagem, a promoção do multiculturalismo e dos ideais de tolerância e convivência pacífica entre diferentes culturas, a política africana.

1. A viagem diz respeito à chegada dos imigrados da costa setentrional da África. Barcos de fortuna, as contínuas tragédias dos náufragos com centenas de mortos, a caça aos traficantes de seres humanos que organizam essas viagens do desespero: são essas as temáticas abordadas neste grupo de canções. A primeira canção que abordava este assunto foi escrita por Samuele Bersani, "Barcarola Albanese" (1997), alusiva às chegadas de migrantes albaneses nas costas da Pulha, no Mar Adriático. Outros compositores que se debruçaram sobre o assunto foram Ivano Fossati, com "Pane e coraggio" ("Pão e coragem”) (2003), Enrico Boccadoro, com "Dov'è la terra capitano" "“Onde é que está a terra capitã") (2005), Gianmaria Testa, com "Da questa parte del mare" ("Deste lado do mar") (2006), Primaluce, com "Sulle ali del mare" ("Nas asas do mar") (2011), Teatro degli Orrori, com "Non vedo l'ora" ("Não vejo a hora") (2012) e Fiorella Mannoia e Frankie HI-NRG, com "Non è un film" ("Não é um filme”) (2012), vencedor do Amnesty International Award.

Geralmente, o conteúdo dessas canções - todas elas escritas na primeira pessoa, singular ou plural - é muito parecido: elas representam a travessia da África do Norte até a Sicília como uma experiência trágica, caraterizada por humilhações e riscos: algo de semelhante a um novo tráfico de escravos. O mar é o símbolo da distância entre as duas costas do Mar Mediterrâneo e duma esperança frustrada, a terra como metonímia para representar tudo quanto existe de caro para quem tem que partir. A Itália é vista como o país da alienação e do medo, uma vez que o primeiro encontro é com a polícia. Entretanto, existem também canções mais otimistas, em que a polarização entre a pátria e o país de chegada é completa e definitiva, em favor deste último, visto como única âncora de salvação.

2. A promoção da ideia duma sociedade multicultural, tolerante e pacífica. É possível distinguir aqui duas grandes tendências temáticas: por um lado, a atenção para 
com a edificação duma sociedade multicultural e duma melhor integração dos imigrados, sobretudo de origem africana; por outro, um posicionamento mais duro e explícito contra todas as formas de racismo,discriminação e intolerância. Algumas das canções mais significativas deste agrupamento são: Pupo, Belli and Youssou N’Dour, "L'opportunità" (“A oportunidade”) (2009); Giorgio Canali e Rossofuoco, "Canzone della toleranza e dell'amore universale" ("Canção da tolerância e do amor universal") (2007); Jessica Lupo, "Orizzonte" ("Horizonte") (2012); Teatro degli Orrori, "Pablo" (2012); Mozait, "Pure Water” (2015), Caparezza, "Io vengo dalla luna" ("Eu venho da lua") (2004).

3. Política africana: se trata de um grupo composto por poucas canções, uma vez que raramente os compositores italianos têm os conhecimentos e a coragem de enfrentar frontalmente questões dessa natureza. Entretanto, os poucos exemplos disponíveis merecem uma menção especial, devido à profundidade dos seus conteúdos e ao resultado artístico no geral. Os dois que aqui serão mencionados são "Rwanda" de Paola Turci (2005), e "Gli Stati Uniti d'Africa" "“Os Estados Unidos de África”) do Teatro degli Orrori (2012). A primeira canção traz inspiração do genocídio em Rwanda, e foi premiada como vencedora da quarta edição do Amnesty International Italian Award. Mediante um rock instintivo, Paola Turci consegue reproduzir a incrível atmosfera que a temática impõe, com uma série de tristes e macabras imagens, tipo: "E o rio agora empurra os seus mortos para Oeste".

A outra canção que lida com questões políticas africanas, interpretada pela banda Teatro degli Orrori,assenta na ideia de promover uma maior unidade entre os países que compõem o continente africano. Recordando Nkrumah, os estados unidos da África são interpretados como "uma maravilhosa utopia”, uma "grande ideia", "uma boa notícia"; entretanto, o fecho da canção assume contornos de pessimismo, uma vez que esta utopia manter-se-á tal, pois nunca se realizará.

\section{Conclusões}

Este artigo teve o objetivo de dar um quadro sintético sobre as formas de representação da África e dos Africanos na música ligeira italiana contemporânea. Os resultados deste primeiro trabalho sobre um tema insólito para os estudos musicais, culturais e até africanos na Itália devem ser considerados de provisórios e suscetíveis de sucessivas alterações e correções. De qualquer maneira, é possível tirar as seguintes ilações:

1. Existem pelo menos quatro grandes fases com que a música italiana, desde o fim do segundo conflito mundial até hoje, aborda a "questão africana". Essas fases estão diretamente relacionadas com a altura histórica e o clima cultural de cada época, confirmando um dos eixos teóricos fundamentais que está na base deste trabalho. As primeiras duas fases, embora muito diferentes entre elas, tendem a coisificar o sujeito "África". A partir da terceira fase, introduzida por composi- 
tores italianos como De Gregori e Daniele, a relação objetual começa a mudar, introduzindo elementos primeiro de reciprocidade, centrados basicamente na figura do Africano imigrado, depois, com os rappers Ítalo-Africanos, revertendo por completo o ponto de vista;

2. Os rappers Ítalo-Africanos representam a verdadeira inovação do panorama musical italiano. Filhos duma cultura juvenil e urbana, os artistas têm absorvido a influência dos meios culturais e musicais em que levaram os seus primeiros passos, nomeadamente a cultura hip-hop e o rap como forma privilegiada de expressão musical. Do ponto de vista mais sociológico, eles conseguem reverter a relação objetual "nós” (Italianos) - "eles" (Africanos) em várias maneiras: acima de tudo, agudizando o olhar crítico para com a cultura, as práticas, a forma de consideração que a sociedade italiana sempre tinha expressado relativamente ao "estrangeiro imigrado", sobretudo se africano e preto, realçando uma postura discriminatória e por vezes abertamente racista. Em segundo lugar, querendo afirmar a sua italianidade, com uma clara distinção relativamente às primeiras gerações de imigrados, ou seja, os seus próprios pais. Distanciar-se deles significa aproximar-se à plena integração na nação que eles consideram como a própria. Assim sendo, regista-se aqui uma certa diferenciação com os outros rappers de origem africana que atuam na França, Inglaterra etc. Nesse caso, provavelmente, o que joga em favor duma postura tão diferente é a questão da nacionalidade: a rede G2, que também representa um elemento de novidade absoluta no panorama musical italiano, tem como seu objetivo primário a mudança do direito de cidadania do Ius sanguinis ao Ius soli. E interpreta esta condição jurídica como profunda injustiça, mas ao mesmo tempo como porta de acesso para o gozo dos direitos fundamentais de cidadania. Nos outros grandes países europeus este problema não existe, uma vez que, na maioria dos casos, a questão jurídica tem sido ultrapassada há muito tempo. Isso significa que os jovens rappers de origem africana podem concentrar os seus esforços identitários na recuperação das suas raízes culturais, operando uma distinção e não uma aproximação com os seus concidadãos "nativos”. Esse elemento representa um dos traços típicos dos rappers Ítalo-Africanos, e será interessante ver se esta postura será mantida, uma vez ultrapassada a atual barreira jurídica (a lei sobre a cidadania já está à atenção do Parlamento há muitos meses);

3. Ao nível cultural mais geral, a esfera pública italiana, tradicionalmente bastante conservadora, tem sido sacudida por algumas das canções e das declarações desses artistas. Como mostrado ao longo do trabalho, sobretudo políticos e jornais da direita manifestaram a sua contrariedade diante das provocatórias afirmações desses artistas, invocando perigos de ordem pública, relacionando terrorismo islamita com rapper "étnico". O resultado é, sim, uma terrível mistura que revela a ignorância sobre o tema, mas também a força deste grupo em obrigar mesmo 
quem não queria a confrontar-se com temáticas consideradas incómodas e de segundo plano;

4. Em termos musicais, os maiores representantes da rede G2 terão ainda que progredir e melhorar, mas a sua força tem sido a capacidade de mesclar ritmos diferentes, derivantes de tradições e até de universos musicais geralmente surdos uns com os outros, usando uma interessante Koiné linguística e, em última instância, experimental. Coisa que a música melódica italiana raramente tem conseguido fazer com eficácia;

5. Fora do contexto musical no sentido estreito da palavra, os rappers Ítalo-Africanos têm desencadeado uma série de iniciativas culturais e de sensibilização no sentido da construção duma sociedade mais tolerante e multicultural que também têm contribuído bastante ao alargamento da esfera pública, atraindo a atenção da comunicação social italiana, mas talvez ainda mais estrangeira, surpreendida pela inesperada vitalidade desses músicos italianos de segunda geração.

\section{Referências}

ADORNO, Theodor. Philosophy of Modern Music. New York: Continuum, 2004.

AHMED, Ebla. Valentino Ag e il rap della Seconda generazione. Frontierenews. 2012. Disponível em: <http:// frontierenews.it/2012/03/valentino-ag-il-rap-della-seconda-generazione/>. Acesso em: 25 maio 2015.

AODREN. Karima, la talentueuse italienne militante, Djolo Cultures d'Afrique, 2015. Disponível em:< djolo.net>. Acesso em: 02 out. 2016.

BASSAN,Valerio .Da Torpignattara al successo, la lunga strada di Amir. Linkiesta, 2012. Disponível em: < http:// www.linkiesta.it/amir-issaa>. Acesso em: 25 maio 2015.

BELLU, Giovanni Maria.Sono un milione i figli di stranieri nati in Italia. La Rete 2G: "Che fine ha fatto la legge sulla cittadinanza?” .Disponível em:<http://notizie.tiscali.it/articoli/cronaca/14/12/17/stranieri-italiacittadinanza.html>. Acesso em: 25 maio 2015.

BENJAMIN, Walter. The Work of Art in the Age of Mechanical Reproduction. USA: Harvard, 2008.

BERGER, Peter; LUCKMANN, Theomas. The Social Construction of Reality. New York: Anchor Books, 1966.

BLANCHARD, Becky. Poverty \& Prejudice: Media and Race. 1999. Disponível em: <https://web.stanford.edu/ class/e297c/poverty_prejudice/mediarace/socialsignificance.htm>. Acesso em: 13 jun. 2015.

BUSSOTTI, Luca. La cittadinanza degli italiani. Milano: Angeli, 2002.

BUSSOTTI, Luca. A representação da África na música italiana contemporânea: das primeiras experiências coloniais ao fascismo. Cescontextos, n. 14, 2016, p. 64-83. Disponível em: <www.ces.uc.pt/cescontextos>. Acesso em: 08 jun.2016.

CLARK, Msia Kibona. Hip hop as Social Commentary in Accra and Dar es Salaam. African Studies Quarterly, v. 13, n. 3, p. 23-46, 2012.

CS 53. Fiorella Mannoia vince il Premio Amnesty Italia 2012 con "Non è un film”, il brano scritto da Frankie HI-NRG, 2012.Disponível em:<http://www.amnesty.it/Fiorella-Mannoia-vince-ilpremio-Amnesty-Italia-2012>. Acesso em: 15 jun. 2015

CUSTOVIC, Alen. Il successo dei media etnici. Reset Doc, 2010. Disponível em: <http://www.resetdoc.org/ story/00000021123 >. Acesso em: 03 out. 2016. 
DEREGIBUS, Enrico.Francesco De Gregori: Mi puoi leggere fino a tardi. Firenze: Giunti, 2003.

DOWD, Timothy.The Sociology of Music. In: BRYANT, C. D.; PECK, D. L. (Ed.). 21st Century Sociology: A Reference Handbook (Volume 2). Thousand Oaks, CA: Sage, 2007, p. 249-260.

EYERMAN, Ron; JAMISON, Andrew. A. Music and Social Movements. Cambridge: Cambridge University Press, 1998.

FABIANI, Tullia. "Noi, Italiani di alter razze”: La seconda generazione in rap. La Repubblica, 2008.

FALDINI, Franca; FOFI, Goffred (Ed.). L'avventurosa storia del cinema italiano: 1933-1959. Milano: Feltrinelli, 1979.

FASCINA, Camilla. Hip-hop culture invasion: A dialogue between America and Italy. Iperstoria, 2015, n. 6, p. 304314. Disponível: <www.iperstoria.it>. Acesso em: 29 jun. 2016.

FERRARI, Paolo. Hip-Hop. Firenze: Giunti, 2000.

FIORENTINI, Barbara. I giornali degli stranieri. Alcune indicazioni per le biblioteche multiculturali. Bibliotime, v. 8, n. 2, 2005.

GILROY, Paul. Against Race: Imaging Political Culture beyond the Colour Line. Cambridge: Harvard UP, 2000.

GOONAN, Danielle.Intercultural Relations and Hip-Hop in Italy. CSC Newsletter, 2009. Disponível em: <https://www.2.dickinson.edu>.Acesso em: 29 jun. 2016.

GIORDANO, Paolo. Quell'odio a ritmo di rapdove ‘balla' il deputato Pd. Il Giornale, 2015.

HABERMAS, Jürgen. The Structural Transformation of the Public Sphere: An Inquiry into a Category of Bourgeois Society. Cambridge: Polity, 1992.

HARGREAVES, David. The functions of Music in Everyday Life: Redefining the Social in Music Psychology. Psychology of Music, 01 mar. 2015, p. 155-170.

IVIC, Damir. Storia ragionata dell'hip hop italiano. Roma: Arcana 2010.

KELLER, Marcello. Musica e sociologia. Milano: Rizzoli, 1996.

KITWANA, Bakari. The Hip-hop Generation. New York: Basic Civitas Books, 2002.

LAFFRANCHI, Andrea. Il “Rap per immigrati” di Amir. Corriere della Sera, 2006.

LE VINE, Mark. When Art Is the Weapon: Culture and Resistance Confronting Violence in the Past - Uprising Arab Springs. Religions, n. 6, 2015, p. 1277-1313.

MARCUSE, Herbert.Art as a Form of Reality. New Left Review, n. 74, 1972.

MICOCCI, Stefano.Canzoni in tempo reale. Vivaverdi, n. 3, Maggio-Giugno 2005, p. 8-12.

MITCHELL, Tony. Introduction. Another Root - Hip-Hop outside the USA. In: MITCHELL, T. (Ed.). Global Noise . Middletown: Wesleyan University Press, 2001.

MONCERI, Flavia. Musica e razionalizzazione in Max Weber: Fra Romanticismo e Scuola di Vienna. Napoli: ESI, 1999

NICASTRO, Annalisa. Karima 2G, s. d. Disponível em: <www.sound36.com>. Acesso em: 02 out. 2016.

OSMETTI, Claudia. Khalid Chaouki (Pd) recita nel video rap di Amir Issaa che incita all'odio. Libero, 2014.

OSGERBY, Bill. Subcultures, Popular Music and Social Change:Theories, Issues and Debates. In:The Subcultures Network (Ed.). Subcultures, Popular Music and Social Change. Cambridge: Cambridge Scholar Publishing, 2014, p. $1-48$.

PAGANO, Giuseppe.Amir Issaa, il rapper che parla con Renzi: "Diritto di cittadinanza a chi nasce qui?Questione di civiltà”.Il Fatto Quotidiano, 2015.

PERILLI, Benedetta. Etimologia di una hit: dall'ALLIGALLI a SIMBALAIÊ ecco cosa significano i tormentoni dell'estate. La Repubblica, 11ago. 2011. Seção Spettacoli \& Cultura. Disponível em:< http://www.repubblica.it/ spettacoli-e-cultura/2011/08/11/news/etimologia_di_un_tormentone-20318415/>. Acesso em: 14 mar. 2016. 
POLCHI, Vladimiro. Le "grida d'allarme" della Lega Nord e di Gasparri \& Co. per il rapper e il deputato marocchino del Pd. La Repubblica, 2014.

ROBERTO. Karima, voce delle seconde generazioni, lancia "Orangutan": il video del primo singolo del suo debutto. 2014. Disponível em:<http://ecodellanotizia.com/karima-voce-delle-seconde-generazioni-lanciaorangutan-video-singolo-suo-debutto/>. Acesso em: 25 maio 2015.

ROSE,Tricia. Black Noise:Rap Music and Black Culture in Contemporary America. Hanover:Wesleyan University Press \& University Press of England, 1994.

ROY, William; DOWD, Timothy. What Is Sociological about Music? Annual Review of Sociology, v.. 36, 2010, p. 183-203.

SANZONE, Daniele. Karima canta la seconda generazione. "Fratelli aficani uscite dalla solitudine". Il Fatto Quotidiano, 2014.

SEFA-BOAKYE, Jennifer. First Look Friday: Liberian-Italian MC/Beatmaker Karima's Fiery Brand Of Social \& Political Commentary.Okayafrica, 2014. Disponível em:<www.okayafrica.com>. Acesso em: 02out. 2016.

SHAW, Arnold. Black Popular Music in America. New York: Schirmer, 1986.

SONKO, Alphousseyni. Noi italiani con il permesso di soggiorno. Limesonline, 2009. Disponível em: <http:// www.limesonline.com/noi-italiani-con-il-permesso-di-soggiorno>. Acesso em: 28 maio2015.

SURACI,Paola.Ius Soli, il rapperAmir Issaa scrive al Presidente Matterella. Immezcla, 18 mar.2015.Disponível em:< http://www.immezcla.it/component/k2/item/869-rapper-petizione-seconde-generazioni-immigrazioneminori-stranieri-change-org.html>. Acesso em: 25 maio 2015.

STREET, John; HAGUE, Seth; SAVIGNY, Heather. Playing to the Crowd:The Role of Music and Musicians in Political Participation. The British Journal of Politics E International Relations, 2007, p. 1-17.

TABASSO, Edoardo; BRACCI, Marco. Da Modugno a X Factor, Roma: Carocci, 2010.

THE BLACK BLOG. Karima, "Vogue". 2014. Disponível em:< http://www.vogue.it/en/vogue-black/theblack-blog/2014/06/karima>. Acesso em: 15 mar. 2016.

W.A. Amir Issaa, Italian hip-hop artist, raps about citizenship law. The Guardian, 2013. Disponível em: $<$ http:// www.theguardian.com/world/2013/jan/21/amir-issaa-hiphop-italy-citizenship > . Acesso em: 25 maio 2015.

W.A. Rete G2 Seconde Generazioni. East, n. 47.Disponível em:<http://www.eastonline.eu/attachments/ article/184/east_47_Rete_G2_Seconde_Generazioni.pdf>.Acesso em: 25 maio 2015. 


\title{
The representation of Africa in contemporary Italian music: from the postwar to today
}

\begin{abstract}
This article aims to analyse how Italian contemporary music represented Africa and the Africans in the postwar period. In a first phase, Italian music neglected completely Africa as a subject to be treated in its songs, probably due to its inglorious colonial and fascist past. After some "light" songs which, during the 1960s, represented the Africans in a folkloric way, some committed Italian songwriters proposed a different image of Africa: firstly, as a far, desirable and "nostalgic" world and thus denouncing the conditions of migrants in Italy, especially of African origins. Finally, a more internal point of view emerges thanks to a group of young Italian-African (as of Italian-Asian) rappers, able to "invert" the perspective through which Italian music had looked at Africa until that moment. The article adopted a qualitative methodology, emphasizing the analysis of the contents of the songs and using interviews which the songwriters here considered gave to newspapers, blogs and some Italian sites.
\end{abstract}

Keywords: image, Africa, songwriters, Italian-African Rappers, citizenship.

\section{Representación de África en la música italiana contemporânea: después de la guerra hasta hoy}

\section{Resumen}

El objetivo de este artículo es analizar cómo la música italiana contemporánea representa África y los africanos en el período Post-Segunda Guerra Mundial. En la primera fase, la música italiana descuidó por completo a África en sus canciones, quizás por causa de su pasado colonial sin gloria y fascista. Después de algunas canciones "ligeras" que a lo largo de los años sesenta, representaron a los africanos de una manera folclórica, algunos compositores comprometidos propusieron una imagen diferente de África: primero como un mundo lejano, deseable y "nostálgico", y después denunciando las condiciones de los inmigrados en Italia, sobre todo los de origen africana. Finalmente, un punto de vista más interno emerge gracias a jóvenes "rappers" ítalo-africanos (así como ítalo-asiáticos) capaces de "invertir” la perspectiva con la que la música italiana, hasta entonces, había observado África. El artículo utilizó una metodología cualitativa, basada en el análisis del contenido de las canciones y algunas entrevistas con cantantes presentes en la esfera pública.

Palabras clave: imagen, África, compositores, Rappers Ítalo-Africanos, ciudadanía. 
